University of Nebraska - Lincoln

DigitalCommons@University of Nebraska - Lincoln

$4-22-2020$

\title{
Pre COVID-19 Market Conditions Persist \& the Stocker Industry Can Dampen the Damage
}

\author{
Elliott James Dennis \\ University of Nebraska - Lincoln, elliott.dennis@unl.edu
}

Follow this and additional works at: https://digitalcommons.unl.edu/ageconfarmmgmt

Part of the Agribusiness Commons, Entrepreneurial and Small Business Operations Commons, Management Information Systems Commons, Other Business Commons, Other Economics Commons, and the Other Immunology and Infectious Disease Commons

Dennis, Elliott James, "Pre COVID-19 Market Conditions Persist \& the Stocker Industry Can Dampen the Damage" (2020). Extension Farm and Ranch Management. 28.

https://digitalcommons.unl.edu/ageconfarmmgmt/28

This News Article is brought to you for free and open access by the Agricultural Economics Department at DigitalCommons@University of Nebraska - Lincoln. It has been accepted for inclusion in Extension Farm and Ranch Management by an authorized administrator of DigitalCommons@University of Nebraska - Lincoln. 


\title{
Pre COVID-19 Market Conditions Persist \& the Stocker Industry Can Dampen the Damage
}

\author{
Dr. Elliott Dennis \\ April 22, 2020
}

The effects of COVID-19 on the livestock market are well known and felt. Some effects include depressed futures and cash prices, unusual basis patterns, decreased packer bids and sale barn volume, packing plant closures, consumer hording of meat products, and shifting food service products for retail consumption. All these effects occurred as market participants grappled with everchanging government and industry policy which reduced consumer demand and resulted in bottlenecks and increasing supply gluts upstream. Simultaneously reducing demand and increasing supply always cause prices to plummet, and in the case of COVID-19 very rapidly. Some segments of the market are likely to begun to stabilize as government lockdown restrictions are lifted. However, the beef complex still has significant supply and demand issues to sort through in the coming months.

\section{Market Conditions Pre-COVID-19 Meltdown}

Since the middle of February, the national and local news media has largely focused on the impacts and changes to the beef complex due to COVID-19. Lost, at least for some time, has been the supply and demand conditions that existed prior to the virus and to some extent still exist today. Here I review some of those market conditions as well as a key segment of the beef supply chain that allows for the beef complex to adapt to intermediate supply and demand disruptions.

In the first part of 2020, most market analysts had forecasted increasing prices due in large part to the following:

1) signed and ratified trade deals with China, Japan, USMCA with Mexico and Canada, and increases in the European Union export limit.

2) ongoing outbreak of African Swine Fever (ASF) in China, Southeast Asia, and Eastern Europe leaving a global protein defect that would be difficult to fill even with record production levels

3) slowing down and leveling off the U.S. beef herd expansion as fewer heifers were retained for breeding and beef cows due to record level cull cow slaughter in the fall

4) strong domestic protein demand due to many items being featured in retail ads

These four key market conditions all pointed to higher prices for cattle producers. This is noteworthy since conditions one to three have and still apply to the cattle industry. All trade deals are still in place and during this COVID-19 situation exports have generally stayed above the historical five-year average. In other words, export demand for beef and veal products is still relatively strong with a strong currency exchange rate. ASF is still ongoing in China and Southeast Asia and repopulation efforts are still failing. The OIE reports many current and active cases in China whereas most of the ASF resolved cases are in Vietnam. This implies that there will continue to be a supply shortage of pork and other protein products in both the near and immediate global future. The herd has not grown in the last six months. If anything, it has shrunk. Thus, the only market condition that existed prior to COVID-19 that led to bullish market price forecast that does not exist today is strong domestic demand. This will be a concern for the industry as beef consumption decreases as the macroeconomy decreases. Likewise, consumers have become price sensitive 
to beef products since the 1980 s (i.e. if beef prices change by $1 \%$, they will decrease consumption $>1 \%$ ). Finally, only about $80 \%$ of beef and veal products are exported. So, while export demand has remained strong, the beef complex still heavily relies on domestic demand to support feeder and fed cattle prices.

\section{Stocker Cattle Act as a Buffer to Manage the Flow of Cattle Through the Beef Complex}

One of the biggest disruptions that all livestock industries faced during the COVID-19 situation was a packing plant work force that was either sick or did not show up to work. This led to packing plants either reducing daily production capacity or closing plants all together. These geographically dispersed and clustered plant shutdowns caused bottlenecks in the production supply chain as producers with fat cattle ready for slaughter were unable to find hook space or bids. Feedlots responded to reduced packing capacity and lagging domestic demand by placing less cattle on feed. The weight distribution of cattle that were placed suggested that feedlots perceived this shock to be short run given larger reductions in $800+\mathrm{lb}$. cattle relative to $<600 \mathrm{lb}$. cattle placements. Feeder cattle not purchased by feedlots either stayed on the home ranch or were transferred out to stocker operations.

The stocker operation is a unique feature of the beef supply chain. Broadly speaking, a stocker operation is any operation that engages in postweaning growing programs that produce commercial feeder cattle (for example, a retained-ownership component of a cow-calf operation or a separate commercial enterprise on grass). So functionally, stocker cattle are weaned calves not yet placed in feedlots but intended for sale as feeder cattle. This segment of the operation exists because of the availability of cheap feedstuff such as grass, hay, and distiller grains. It should not be understated that the beef industry has been better able to respond to the COVID-19 situation because of the timing of the virus. The US lockdown began in March and restrictions began to be lifted in May. Cattle were coming off winter forage had the ability to transition to spring and summer grass. The availability of these cheaper feed sources, relative to corn, has greatly reduced the impact of COVID-19, much more so than in the hog and poultry industry.

\section{Market Size and Distribution of Stocker Cattle}

So, what does the geographic stocker supply look like heading into the spring and summer of 2020 ? The stocker index is a commonly used metric to determine the net movement of feeder cattle within a state. It is calculated as the current feeder supply divided by the calf crop in the previous year. Figure 1 plots the stocker index for all states which USDA collects data using January 2020 data. A few highlights should be noted. First, Kansas, Oklahoma, and Iowa are the three states with the largest stocker cattle moving into 2020. Second, operations located in the South East and Western States are below the US average indicating more cattle leaving the state than entering. Third, states with the most stocker cattle appear to be in and around the Eastern Corn belt. So, what does this potentially imply for feeder cattle prices in these areas? Assuming constant local demand and negligible cattle quality differences would imply that feeder cattle prices in states where the stocker index is above (below) the US average would be lower (higher). How much lower (higher) likely depends on the time of year feeder cattle are purchased.

\section{Managing Cattle through and out of the COVID-19 Crisis}

While the stocker industry has helped dampen the supply chain fiasco due to COVID-19 cases among packing plant workers, the efficacy of this supply buffer largely rests on the availability of cheap forage relative to corn. If the pasture and range conditions remain in very good to good conditions the longer cattle can be held outside feedlots. However, if pasture and range conditions worsen then more cattle will need to 
enter the feedlot putting downward pressure on feeder cattle prices. While weather is geographically varied, overall 2019 was a very wet year with pasture rated poor or very poor consistently $5-10 \%$ lower than the historical five-year average throughout the summer and into the fall. In other words, the data suggests that feed resources are going to be tighter in the summer than last year.

Weather predictions from NOAA would tend to confirm that this year is likely to be warmer that what has been experienced in the past. Temperature tends to oscillate from warm to cool in patterns that span multiple years. The U.S. and Midwestern Plains in particular, are coming out of the cooling cycle and temperatures could rise. NOAA predicted in April 2020 that there is a $60 \%$ chance that the weather will be warmer in autumn than in previous years. The accuracy of this prediction as well as where forage conditions worsen first will have a lot to do with the local pricing of feeder cattle and the future supply of feeder cattle.

So, what does all this mean for managing feeder cattle price risk? The long and short is know your cost of production, find a futures price that maximizes profit, and lock it in using available risk management tools recognizing that maximum profit this year could be negative. Available risk management tools include futures, options, or Livestock Risk Protection (LRP). One lesson that our industry has painfully learned over the past year or so through the Holcomb fire and now COVID-19 is the urgent need to aggressively and actively manage price risk in all parts of the production process - both the actual price level and price variation. 


\section{Tables and Figures}

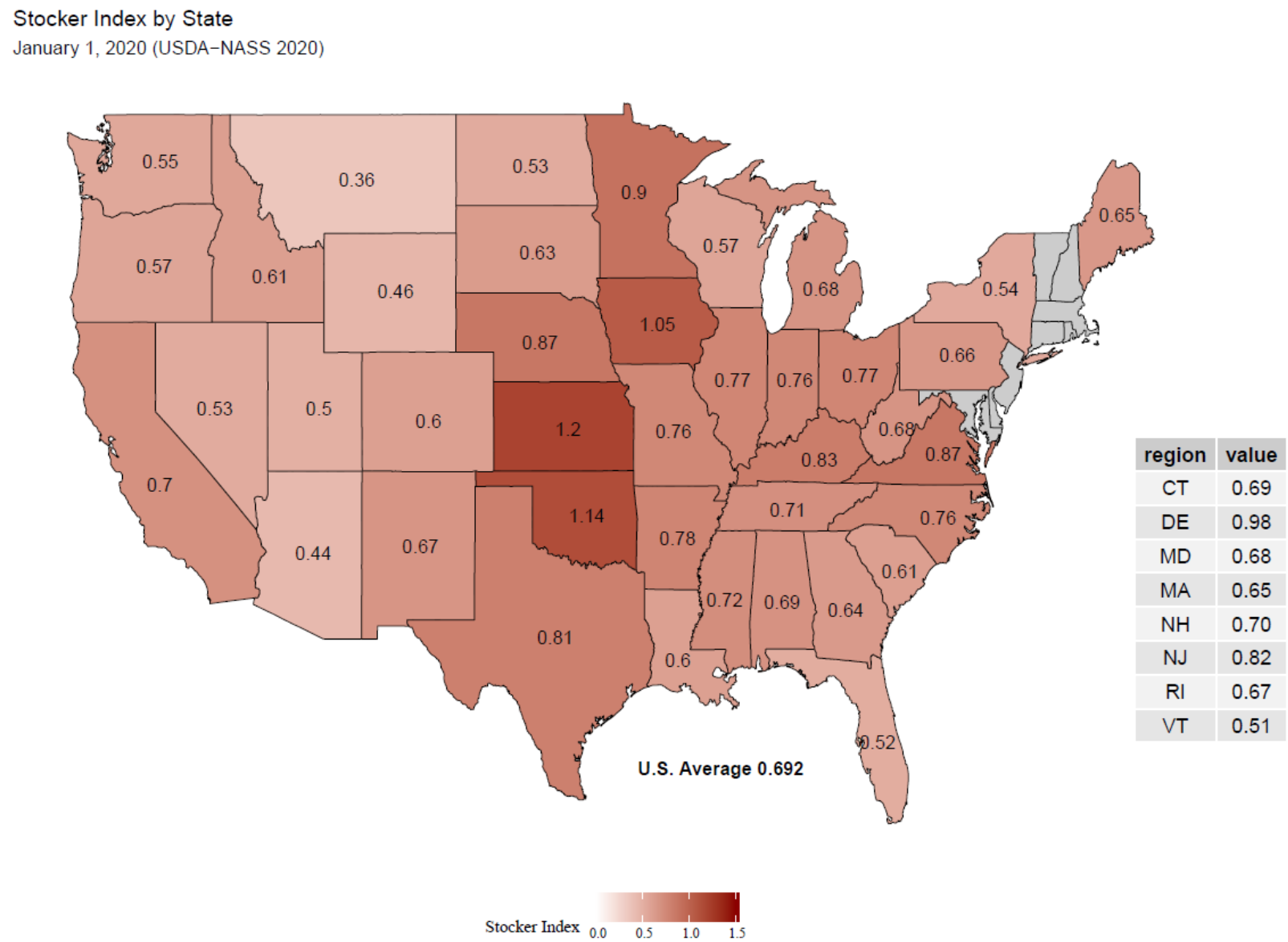

Figure 1. Stocker Index by State in 2020 (USDA-NASS 2020)

Elliott Dennis is an assistant professor and livestock marketing economist in the Department of Agricultural Economics. 